\title{
Nest sites of feral honey bees in California, USA
}

\author{
P Gambino *, K Hoelmer, HV Daly \\ Department of Entomological Sciences, 201 Wellman Hall, University of California, Berkeley, USA
}

(Received 9 December 1988; accepted 22 June 1989)

\begin{abstract}
Summary - Nest site characteristics are described for 94 honey bee nests in trees, 17 in the ground, and 82 in man-made structures. Nests were in trees of mean diameter $85 \mathrm{~cm}$ primarily in live hardwoods, especially oaks. Entrances were mostly single knots or cracks in the main trunk at ground level and up to a mean height of $2.5 \mathrm{~m}$. Most nests in the ground were in treeless areas; half had partially exposed combs, possibly aiding ventilation. Nests in buildings differed from those in trees by having smaller entrances. Compass orientation of comb in natural nest sites was commonly from $145^{\circ}-195^{\circ}$.
\end{abstract}

Apis mellifera / feral colony / nidification / nest site

\section{INTRODUCTION}

The natural nesting sites of honey bees (Apis mellifera $L$ ) in the USA have only recently been studied in detail. Avitabile et al (1978) analyzed characteristics of 108 "bee trees" in Connecticut. Seeley and Morse (1976) described 39 tree nesting sites in New York, including details of the cavities and combs of 21 of these. Taber (1979) monitored 21 feral colonies in central Arizona over a period of 5 years. We describe here site characteristics of 94 nests in trees and 17 in the ground in California, encompassing a much wider geographic area and variety of habitats than in previous studies. We include data on an additional 82 feral colonies nesting in artifi- cial structures. Our information was gathered while we collected feral bees for a morphometric study which will be described elsewhere.

\section{MATERIALS AND METHODS}

The locations of feral colonies in natural sites and artificial structures in 25 counties of California were relayed to us through personal contacts and in response to letters sent to land managers throughout the state. Most of the nests in trees were in park, rural, and wildland habitats. The sample was biased to include nests near human activity and within sight of observers on the ground. We made observations while bees were active during our sampling visits to the entrances of 73 nests in natural sites and 32 in artificial structures. Data on an addi-

\footnotetext{
* Present address: Hawaii Volcanoes National Park, Field Research Center, Box 52, Hawaii National Park, HI 96718. Correspondence and reprints.
} 
tional 38 natural and 50 artificial sites were provided with bee samples sent to us by project cooperators. As much of the following data as possible was gathered for each colony: date of observation; county; locality; identity of tree (family and genus) and diameter at breast height (dbh, at 1.6 meters) for tree nests; shape and area of opening (dimensions of the opening were measured and the area of the regular polygon most closely approximating the shape of the entrance was computed); height of the bottom of the entrance above ground; compass orientation of entrance (magnetic north $=0^{\circ}$ ); and compass orientation of combs (the long comb axis when viewed from above).

Nest cavities were not opened and incomplete data were obtained for some nests. Nests with multiple openings (5 from trees and 2 from buildings) were excluded from analysis of entrance height, area, and orientation. Nest types were classified as tree, ground, or artificial to allow comparison of site characteristics between these categories. For ground nest entrance height comparisons, only the subset of nests in cliffs or vertically oriented surfaces was considered.

Since distributions were irregular, median and mode are included with descriptive statistics. Significance values for comparisons among entrance areas (of less than $1000 \mathrm{~cm}^{2}$ ), entrance heights, and tree dbh are based on the Kruskal-Wallis $\mathrm{H}$ statistic corrected for ties and compared to the $\chi^{2}$ distribution. Statistical analyses were performed with SPSSx (Anonymous, 1986), except for directional nest entrance orientation and comb orientation data, analyzed using Rayleigh's test (Batschelet, 1981).

\section{RESULTS}

\section{Nests in Trees}

Of 94 nests in trees, all but 6 were in living trees. We were able to identify the genus of the host tree for 82 nests; 1 colony was found in a palm tree of unspecified genus; and 11 were from unidentified live or dead trees (table I). For the 82 colonies, we collected information on tree size from 51 (fig 1), height of entrance from 50 (fig 2), entrance size from 40 (fig 3), location (base, trunk, limb) and type of entrance (knot, crack) from 37 (table II), compass orientation of entrance from 44 (fig 4), and orientation of combs from 7 (fig 5 ).

Most entrances ( 32 of 37 , or $86 \%$ ) were located on the trunks of trees. Of the 32 entrances, 24 were on the main trunk (12 at knots; 12 at cracks) and 8 at the base of the tree ( 6 openings wider than high; 2 at vertical cracks). Five nests on limbs were at the stubs of broken limbs (4) or at a knot (1). One additional colony was not in a cavity, but constructed in the space between the trunk and hanging fronds of a date palm (Phoenix) tree.

\section{Nests in the ground}

Seventeen colonies were in cavities or shallow recesses in the ground (6) or cliff faces (11). Of the 13 visited, 3 had entrances on fairly level ground, 8 had openings in vertical or steep cliffs, and 2 in cliffs had mostly exposed combs. Twelve of the colonies visited were in desert areas with trees either absent or sparse; the remaining colony was in a coastal coniferous forest. We measured the entrance area of 10

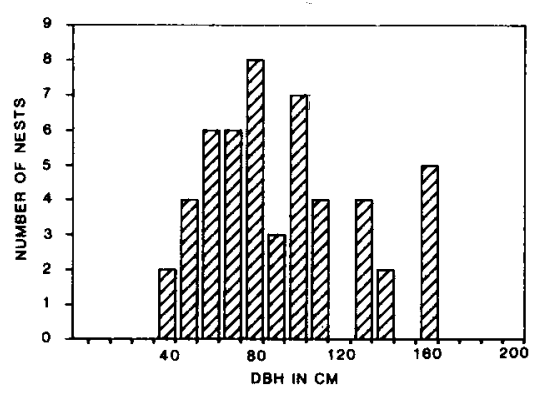

Fig 1. Distribution of tree $\mathrm{dbh}(\mathrm{cm})$ for 51 nests. Mean $=85.59$; $\mathrm{sd}=33.57$; median $=76$; mode class $=70-80 ;$ range $=38-152$. 
Table I. Trees occupied by nesting feral colonies *.

\begin{tabular}{lllr}
\hline Family & Genus & Common Name & $\begin{array}{c}\text { Number } \\
\text { of colonies }\end{array}$ \\
\hline Fagaceae & Quercus & Oak & 43 \\
Myrtaceae & Eucalyptus & Gumtree & 10 \\
Platanaceae & Platanus & Sycamore & 8 \\
Anacardiaceae & Schinus & Peppertree & 5 \\
Cupressaceae & Cupressus & Monterey Cypress & 4 \\
Lauraceae & Umbellularia & Bay & 2 \\
Leguminosae & Robinia & Black Locust & 2 \\
Ulmaceae & Ulmus & Elm & 2 \\
Bignoniaceae & Catalpa & Catalpa & 1 \\
Oleaceae & Olea & Olive & 1 \\
Palmae & Phoenix & Date Palm & 1 \\
Palmae & unspecified & "palm" & 1 \\
Tamaricaceae & Tamarix & Tamarix & 1 \\
Moraceae & Morus & Mulberry & 1 \\
Agavaceae & Yucca & Joshua Tree & 1 \\
Unidentified & & & 11 \\
\hline
\end{tabular}

" Family names according to Bailey and Bailey (1976).

nests (fig 3), orientation of entrance of 9 (fig 4), orientation of combs of 4 (fig 5), and entrance height of 8 cliff nests (fig 2). Of the four not visited, 2 were reported from crevices in a rock or cliff, 1 was dug from the ground, and 1 was found in a brush pile.

\section{Nests in artificial structures}

Eighty-two colonies were reported from various types of artificial structures, most often in buildings $(62$, or $76 \%)$. Colonies in the latter were found in an attic, eaves, a light fixture, under the roof, in vent fans, and within walls. The space between walls was the most frequent location for nesting sites in buildings (41 out of a total of 62 , or $66 \%$ ). In other artificial structures, nests were found under a doghouse, in wood duck nesting boxes, a barbecue, a tractor, a food locker, a packing crate, an ice box, an abandoned beehive, and in various pipes and housings for pumps, wells, and exhaust systems associated with irrigation systems or with oil-field machinery.

We measured the height of entrance for 16 nests in buildings (fig 2). For nests in buildings and other structures, we measured the entrance size of 19 nests (fig 3), the compass orientation of entrance of 23 nests (fig 4), and comb orientation of 5 nests (fig 5).

\section{Height of nest entrance}

The 3 distributions of height of nest entrance in trees, buildings, and clifts were 

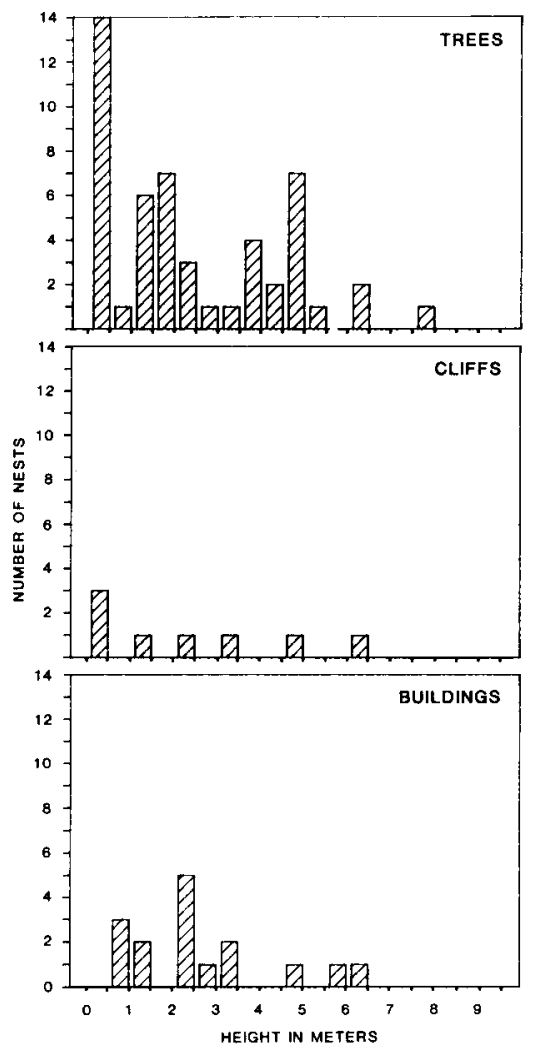

Fig 2. Distribution of height $(m)$ of entrance from ground level to bottom of nest entrance for: 50 tree nests (mean $=2.28$; sd $=2.05$; median $=1.53$; mode class $=0-0.5 ;$ range $=0$ 7.63 ), 8 nests in cliffs (mean $=1.34$; $s d=2.15$; median $=1.86$; mode class $=0-0.5$; range $=0-$ 6.10 ), 16 nests in buildings (mean $=2.64$; $\mathrm{sd}=$ 1.61; median $=2.46$; mode class $=2.0-2.5$; range $=0.62-6.15$ ) .

not different (fig $2 ; \chi^{2}=1.23 ; \mathrm{df}=2 ; P>$ 0.05 ). Mean height of entrances in 50 trees was $2.5 \mathrm{~m}$. Some entrances were at ground level, but most were above $(42$, or $84 \%$ ). Height of opening did not differ among the 3 most frequent genera of trees $\left(\chi^{2}=3.32 ; \mathrm{df}=2 ; P>0.05\right)$. Above $5 \mathrm{~m}$ the frequency of nest entrances diminished. This may reflect not only the de-

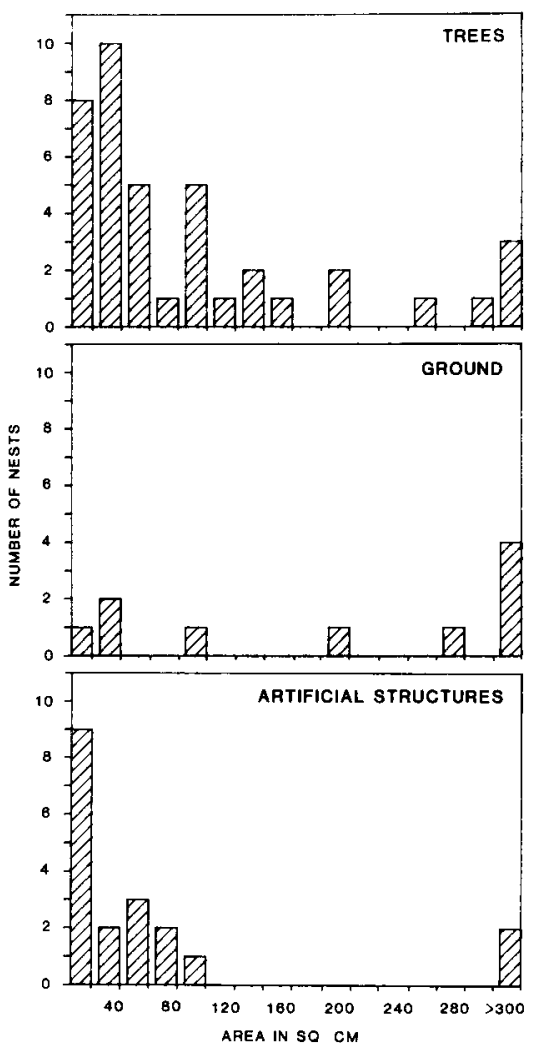

Fig 3. Distributions of nest entrance areas $(\mathrm{cm} 2)$ of: 40 tree nests (mean $=110.30$; $\mathrm{sd}=177.62$; median $=46$; mode class $=20-40 ;$ range $=2-$ 972), 10 ground nests (simple statistics computed on 9 nests after excluding maximum value of $4560 ;$ mean $=285.7 ; \mathrm{sd}=303.13 ;$ median $=$ 182 ; mode class $=20-40 ;$ range $=8-900), 19$ artificial structures (mean $=102.68$; $s d=229.34$; median $=24$; mode class $=0-20 ;$ range $=1-$ 929).

creased size of trunks and limbs, but also increased difficulty in discovering nests higher on trees.

Mean entrance height for 16 nests in buildings was 2.6 (fig 2). Nests in upper stories of multi-story structures might be under-reported because of reduced visibility. Ground-nesting colonies were most of- 
Table II. Comparison of host tree characteristics. Percentages and statistics often computed on less than total number of nests examined; $\mathrm{nr}=$ not reported.

\begin{tabular}{|c|c|c|c|}
\hline Characteristic & This study & $\begin{array}{l}\text { Seeley \& Morse } \\
\quad(1976)\end{array}$ & $\begin{array}{c}\text { Avitabile et al } \\
(1978)\end{array}$ \\
\hline Total nests & 94 & 39 & 108 \\
\hline $\begin{array}{l}\text { Number of host genera } \\
\text { Most common } \\
\text { Second } \\
\text { Hardwoods } \\
\text { Conifers } \\
\text { Monocots }\end{array}$ & $\begin{array}{c}14 \\
\text { Quercus (52\%) } \\
\text { Eucalyptus (12\%) } \\
92 \% \\
5 \% \\
4 \%\end{array}$ & $\begin{array}{c}16 \\
\text { Acer }(33 \%) \\
\text { Quercus }(25 \%) \\
94 \% \\
6 \% \\
0\end{array}$ & $\begin{array}{c}12 \\
\text { Quercus (20\%) } \\
\text { Juglans (13\%) } \\
83 \% \\
17 \% \\
0\end{array}$ \\
\hline $\begin{array}{l}\text { Live trees } \\
\text { Single entrance }\end{array}$ & $\begin{array}{l}94 \% \\
94 \%\end{array}$ & $\begin{array}{l}94 \% \\
90 \%\end{array}$ & $\begin{array}{l}75 \% \\
79 \%\end{array}$ \\
\hline $\begin{array}{l}\text { Tree dbh in cm: } \\
\text { Mean } \\
\text { Range }\end{array}$ & $\begin{array}{c}85 \\
38-152\end{array}$ & $\begin{array}{l}\mathrm{nr} \\
\mathrm{nr}\end{array}$ & $\begin{array}{c}90 \\
30-180\end{array}$ \\
\hline $\begin{array}{l}\text { Primary entrance on } \\
\text { Trunk and base } \\
\text { Limbs }\end{array}$ & $\begin{array}{l}86 \% \\
14 \%\end{array}$ & $\begin{array}{l}\mathrm{nr} \\
\mathrm{nr}\end{array}$ & $\begin{array}{l}72 \% \\
28 \%\end{array}$ \\
\hline $\begin{array}{l}\text { Primary entrance at } \\
\text { Knots or stubs } \\
\text { Cracks } \\
\text { Base or roots }\end{array}$ & $\begin{array}{l}46 \% \\
32 \% \\
22 \%\end{array}$ & $\begin{array}{l}56 \% \\
32 \% \\
12 \%\end{array}$ & $\begin{array}{r}69 \% \\
30 \% \\
1 \%\end{array}$ \\
\hline $\begin{array}{l}\text { Entrance height in } \mathrm{m} \\
\text { Mode class } \\
\text { Median }\end{array}$ & $\begin{array}{c}0-0.5 \\
1.5\end{array}$ & $\begin{array}{l}0-1 \\
1-2\end{array}$ & $\begin{array}{l}2-3 \\
3-4\end{array}$ \\
\hline $\begin{array}{l}\text { Entrance area in } \mathrm{cm}^{2} \\
\text { Mode class } \\
\text { Median }\end{array}$ & $\begin{array}{c}20-40 \\
46\end{array}$ & $\begin{array}{l}10-20 \\
20-30\end{array}$ & $\begin{array}{l}35-40 \\
60-65\end{array}$ \\
\hline $\begin{array}{l}\text { Most frequent orientatic } \\
\text { Entrance } \\
\text { Combs }\end{array}$ & $\begin{array}{l}\text { of of } \\
\text { Random } \\
145^{\circ}-195^{\circ}\end{array}$ & $\begin{array}{l}\text { Random } \\
\text { Random }\end{array}$ & $\begin{array}{c}225^{\circ} \\
\mathrm{nr}\end{array}$ \\
\hline
\end{tabular}

ten associated with openings in vertically oriented surfaces. Mean entrance height for 8 nests in cliff faces was $2.2 \mathrm{~m}$ (fig 2).

\section{Entrance area}

The distributions of areas of nest entrances for nests in trees and artificial structures were variable and roughly bimodal: small openings less than $100 \mathrm{~cm}^{2}$, or very large openings resulting in semi-exposed nests (fig 3). Entrance area varied significantly according to the type of site $\left(\chi^{2}=6.55\right.$; $\mathrm{df}=2 ; P<0.05)$. Openings into artificial structures were mostly cracks or small holes with a median of $24 \mathrm{~cm}^{2}$. Some entrances were just large enough for a bee to enter. The entrances in trees had a larger median of $46 \mathrm{~cm}^{2}$ and were not different 

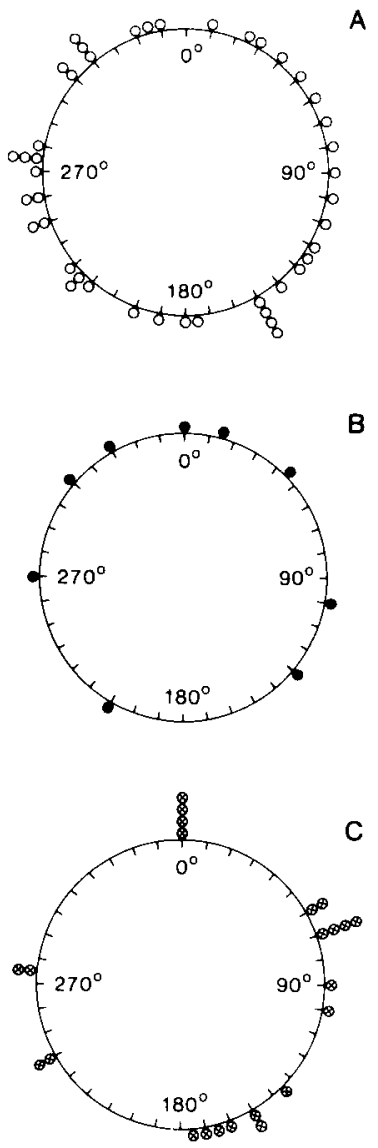

Fig 4. Compass orientation $\left(0^{\circ}=\right.$ north) of nest entrance of A) 44 tree nests; B) 9 ground nests; C) 23 nests in artificial structures.

among the 3 most frequent genera of trees $\left(\chi^{2}=-5.49 ; \mathrm{df}=-2 ; P>0.05\right)$. Entrances in ground nests were often poorly defined and measurement was approximate.

\section{Orientation of nest entrance}

No directional bias of entrance orientation was detected for tree (Rayleigh's $Z=0.29$,

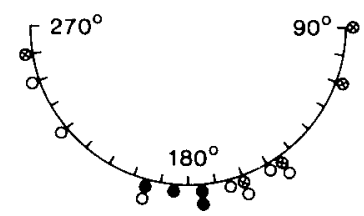

Fig 5. Compass orientation of comb (long axis) for 7 nests in trees (open circles), 4 ground nests (solid circles), and 5 nests in artificial structures (circles with crosses).

$P>0.10, \mathrm{n}=-44)$, ground $(\mathrm{Z}=-0.69, P>$ $0.10, \mathrm{n}=-9)$, or artificial $(Z=-1.78, P>0.10$, $n=-23$ ) nest sites (fig 4).

\section{Orientation of comb}

We measured comb orientation at 13 colonies in natural situations (tree and ground cavities) and 5 colonies in artificial structures. Two of the colonies in natural situations had variable comb orientations, and were excluded from our analysis. Unlike orientation of nest opening, which is unidirectional and can vary throughout 360 degrees, comb orientation is axial and can be uniquely described within any 180 degrees of arc. We express comb orientation as a value between $90^{\circ}$ and $270^{\circ}\left(180^{\circ}=\right.$ - northsouth axis) to best illustrate our findings (figure 5). Data pooled from all samples (trees, ground and artificial structures) show a uniform (or random) comb orientation distribution $(Z=-1.69, P>0.10, n=$ $16)$, as do the data from artificial sites alone $(Z=0.49, P>0.10, n=5)$. There were too few ground nests for statistical evaluation, so data from natural sites (ground and tree nests) were pooled; comb orientation for this set was nonuniform $(Z=3.54, P<0.025, n=11)$, with a mean angle of $184^{\circ}$. 
The 2 colonies in natural situations with variably oriented combs were both largely exposed. One was the colony built on the date palm (Phoenix) tree, in the space between the trunk and a dense shield of hanging dead fronds. Vertical combs (at least 8) were attached to the trunk in a radial arrangement, so that the space between combs at the trunk was less than between the outermost comb portions nearest the fronds. Comb orientation varied from $55^{\circ}$ to $120^{\circ}$. The second set of variably oriented combs was in an abandoned nest in a cavity in a vertical cliff. Ten combs were oriented at $210^{\circ}$ and 3 were oriented at $245^{\circ}$.

\section{DISCUSSION}

Honey bees do not enlarge their nest cavity except to clean and prepare the interior surface of the enclosure. They must make use of pre-existing cavities of either natural or man-made origin. We examined colonies from urban and agricultural areas, and from nature reserves in coastal regions, inland valleys, deserts, foothills, and mountains. Of nest sites in trees, 76 out of 83 $(92 \%)$ in our study, and most of those reported by others (table II), were in cavities in the trunks of live hardwood trees. In California, the only conifer selected by bees, Monterey Cypress, Cupressus macrocarpa, had 4 out of 83 , or $5 \%$ of nests. This species has been planted extensively along the coast of California (Griffin and Critchfield, 1976). Three nests, including the exposed nest, were in monocot trees.

Bees used hardwood trees in 11 families and genera for nest sites, with $85 \%$ of all tree nests in just 5 genera (table 1). Hardwoods in California are estimated to occupy 5-6 million hectares (12-15 million acres) and account for roughly $26 \%$ of the total wood volume of California's forests
(Pillsbury and Kirkley, 1984). Oaks, Quercus spp. , were hosts to $52 \%$ of colonies in trees. This genus was also among the favoured trees reported elsewhere, but at lower frequencies (table II). Oaks are usually dominant in California hardwood communities (Griffin and Critchfield, 1976).

Bee trees reported here and elsewhere are similar in diameter when measured at $1.3-1.6 \mathrm{~m}$ height: minimum, $30-38 \mathrm{~cm}$, and mean, 85-90 cm (table II). Since bees will only make use of cavities larger than about 10 litres (Rinderer et al, 1981; Seeley, 1977), suitably large cavities are unlikely to be found in young trees or those with small diameters. Likewise, the inverse relation between tree diameter and height results in the more likely occurence of suitable cavities at lower heights. In our sample of 50 tree nests the median entrance height was $1.5 \mathrm{~m}$. Since the entrance is usually near the nest cavity (Seeley and Morse, 1976) these data would indicate that in California, the majority of suitable tree cavities are close to the ground. Seeley and Morse (1976) also found a predominance of entrances at or near ground level in New York State, as did Taylor and Otis (1978) for Africanized honey bees in French Guiana. However, Seeley and Morse (1978) found that when bee swarms were offered identical trap boxes $1 \mathrm{~m}$ and $5 \mathrm{~m}$ high they preferred to occupy the higher one. Lacking a means of detecting nests equally well at all heights, we cannot determine the extent to which sampling bias (nests nearer to the ground are easier to detect) affected our measure of nest height distribution.

We found no preferred orientation of the nest entrance, but Avitabile et al (1978) found a predominance of SW facing openings (table II).

Certain features of artificial nest sites were different from those of natural ones. Comb orientation appeared to be more 
variable than in natural sites, but our sample was small. Entrances into buildings were smaller than those in trees, with means of $30.3 \mathrm{~cm}^{2}$ and $69.0 \mathrm{~cm}^{2}$, respectively. Although the entrance heights in buildings were not statistically different from those in trees, we found no entrances at ground level in buildings.

The hot, arid climate and treeless regions of the Southern interior of California would appear to be inhospitable to European bees, yet feral colonies are not totally excluded from even the most barren habitats. Our observations of thriving colonies in deserts are evidence that a proper combination of cavity, exposure, shade, and access to water can create favourable microhabitats for colonies. Furthermore, natural food and water resources are supplemented by irrigation of agricultural and residential developments, thus encouraging colonization of the desert by feral bees.

Twelve of the 13 ground colonies visited were in desert or treeless areas. Without a mantle of soil and vegetation, deserts may have a high frequency of suitable ground cavities. Taber (1979) found 20 colonies in cavities in limestone cliffs within a $1 \mathrm{~km}$ radius. In our study partial exposure of combs in ground nests was more frequent than in trees: 7 of the 13 ground colonies (54\%) had the combs visible from the entrance, as opposed to 8 out of $62(13 \%)$ in trees. In addition, openings in the ground were more often larger: only 4 out of 10 ground nests had entrances $100 \mathrm{~cm}^{2}$ or smaller, compared with the median value of $46 \mathrm{~cm}^{2}$ for tree nests. However, even the most fully exposed ground nests were partly tucked into crevices. Taber (1979) also noted exposure of combs in half of the ground-nesting colonies he described in central Arizona. While such exposure might be explained simply as the growth of the colony beyond the capacity of the cavity or the lack of suitable cavities, it may also facilitate ventilation.

Our observation of the general northsouth arrangement of natural combs supports the report of De Jong (1982; but see Ifantidis, 1978; Taylor and Otis, 1978) that bees use the earth's magnetic field for orientation of combs.

Among the colonies we visited were some that were large, vigorous, and at sites that had apparently been occupied for more than a year. Although our collecting methods stimulated mild defensive behaviour by the bees and we occasionally smelled alarm pheromone, we experienced few instances of stinging behaviour. The strongest responses were associated with our attempts to cut away the comb or when we blew into the entrance to increase the activity of bees. None of the colonies examined displayed the intense defensive behaviour ascribed to Africanized bees (Collins et al, 1982).

\section{ACKNOWLEDGMENTS}

We are indebted to Eric Erickson for references on bees and magnetism. We were assisted in gathering data by Arthur Conser, David Gonick, Derham Giuliani and Joe Stone. Christina Jordan helped to prepare the illustrations. Reginald Chapman, Eric Erickson, Roger Morse, and Richard Nowogrodzki reviewed the manuscript and offered suggestions for its improvement. The following beekeeping organizations also contributed data: Alameda County Beekeepers Association, Beekeeper Guild of San Mateo, Inland Empire Beekeepers, Marin County Beekeepers Association, Nevada County Beekeepers Association, Sacramento Area Beekeepers Association, San Francisco Hobby Beekeepers, and Santa Clara Beekeepers Guild. Representatives of the following institutions and enterprises cooperated by arranging for the collection of material: California Department of Parks and Recreation (Ken Hall, James Hendrix, Dennis Im- 
hoff, Hank Nicholl, Dave Sullivan, William Tippets), Chico State University (David Kistner), Colina Del Sol Golf Course, East Bay Municipal Utility District, East Bay Regional Park District (Ira Bletz, Tim Gordon, Alan Kaplan, Steve Quick, John Sofios), National Audubon Society (Peter DeSimone), The Nature Conservancy (F. Thomas Griggs, Rob Hansen, Elwood Hengst, Rick Hewett, Craig Streeper), Orange County Mosquito Abatement District (Steve Bennett), Pebble Beach Company (Gordon Lutes), Point Reyes National Seashore (Russ Lesko, John Sansing), Riverside County Agricultural Commission (Ted Smith), San Diego County Parks (Bob Downer), Salton Sea National Wildlife Refuge (Lee Laziure), San Francisco Zoological Society (Colleen Dibble), San Vincente County Club Golf Course, Singing Hills Golf Course, Stanford University (Nona Chiariello), and the University of California (John Barthell, Jim Burkee, John Connor, Ray D Copeland, Pat Evans, Jim Griffin, Mike Hamilton, Matthew James, Walter D. Koenig, Fran Lile, Chris Moscone, Tim Pearce, Jay Rosenheim, Gary Ulrich, Jan Washburn). Support was provided by the California Department of Food and Agriculture and the University of California Agricultural Experiment Station.

Résumé - Sites de nidification des colonies sauvages d'abeilles (Apis mellifica) en Californie, USA. Les caractéristiques des sites de nidification sont décrites pour 193 nids d'abeilles répartis dans 25 districts de Californie. 94 nids se trouvaient dans des arbres, 17 sur le sol et 82 dans des structures créées par l'homme. Les données recueillies ont porté sur la taille, la hauteur et l'orientation de l'entrée du nid et sur l'orientation des rayons. Pour les nids trouvés dans les arbres, l'espèce botanique et la taille de l'arbre ont été ajoutées.

$94 \%$ des nids situés dans les arbres se trouvaient dans des arbres vivants, 92\% dans des feuilles et $52 \%$ dans des chênes (Quercus) (tableau I). Les trous de vol étaient le plus souvent de simples noeuds ou fissures dans le tronc principal, au niveau du sol et jusqu'à $2,5 \mathrm{~m}$ de haut en moyenne. Le diamètre moyen de l'arbre à $1,6 \mathrm{~m}$ était de $85 \mathrm{~cm}$ (fig 1), le diamètre minimum de $38 \mathrm{~cm}$ et il est peu vraisemblable que des arbres moins gros soient capables de former des cavités suffisamment grandes pour être occupées par une colonie d'abeilles.

Les nids dans le sol étaient la plupart du temps situés dans des zones sans arbres et associés à des surfaces plus ou moins verticales. La moitié d'entre eux avaient des rayons partiellement à l'extérieur, peut-être pour faciliter la ventilation. L'entrée des nids étaient souvent mal définie.

Les bâtiments représentaient $76 \%$ des structures artificielles qui hébergeaient des colonies d'abeilles. $66 \%$ des colonies nidifiant dans des bâtiments occupaient l'espace entre les murs. Dans ces cavités artificielles, les ouvertures conduisant au nid étaient significativement plus petites que dans les cavités naturelles (fig 3 ). La hauteur du trou de vol ne différait pas significativement d'une catégorie de nids à l'autre. La moyenne générale était de 2,25 $\mathrm{m}$ avec une valeur médiane de $1,86 \mathrm{~m}$ (fig 2). L'orientation du trou de vol était aléatoire pour toute les catégories de nids (fig 4). L'orientation des rayons dans les cavités naturelles ne l'était pas : l'axe magnétique nord-sud était privilégié (orientation moyenne : $184^{\circ}$ ) (fig 5).

Apis mellifica / colonies sauvages / nidification / site de nidification

\section{Zusammenfassung - Nistplätze von wildlebenden Bienenvölkern in Kali- fornien. Für die Nistplätze von 193 Bienenvölkern in 23 Bezirken Kaliforniens werden die bezeichneten Eigenschaften beschrieben. 94 Nester befanden sich in Bäumen, $17 \mathrm{im}$ Erdboden und 82 befan- den sich in von Menschen errichteten Strukturen. Es wurden Daten über Größe,}


Höhe und Himmelsrichtung des Flugloches sowie über die Orientierung der Waben gesammelt. Für die Nester in Bäumen wurde die Baumart bestimmt sowie die Größe des Baumes notiert.

Von den Baumnestern befanden sich $94 \%$ in lebenden Bäumen, $92 \%$ in Laubbäumen und $52 \%$ in Eichen (Quercus; Tabelle I). Als Flugloch wurden einzelne Astlöcher oder Risse im Hauptstamm, von Bodenhöhe bis zu einer mittleren Höhe von $2,5 \mathrm{~m}$ benützt. Der mittlere Durchmesser der Bäume in einer Höhe von 1,60 m betrug $85 \mathrm{~cm}$ (Abb 1). Der kleinste Durchmesser betrug $38 \mathrm{~cm}$; es ist unwahrscheinlich, daß noch kleinere Bäume Höhlen bilden können, die zur Aufnahme eines Bienenvolkes ausreichend gro $\beta$ sind.

Die meisten der Bodennester befanden sich in baumlosen Gegenden mit sehr steilen Erhebungen. Viele hatten teilweise exponierte Waben, möglicherweise zur Erleichterung der Ventilation. Die Eingänge zu den Bodennestern waren oft nur ungenau markiert.

Eine Vielfalt künstlicher Strukturen beherbergte Bienenvölker. Gebäude waren am häufigsten ( $76 \%)$; von den Völkern in Gebäuden hatten sich $66 \%$ in dem Zwischenraum zwischen den Hauswänden angesiedelt. Die in den künstlichen Strukturen zur Nisthöhle führenden Eingänge waren viel kleiner als die Fluglöcher von natürlichen Höhlen (Abb 3).

Die Höhe der Fluglöcher über dem Erdboden war bei den drei Nestkategorien nicht signifikant verschieden. Das Gesamtmittel betrug 2,25 $\mathrm{m}$, mit einem Medianwert von 1,86 m (Abb 2). Die Orientierung des Flugloches war für alle Nistkategorien zufällig (Abb 4). Die Orientierung der
Waben in natürlichen Höhlen war nicht zufällig; es wurde deutlich die magnetische Nord-Süd-Achse bevorzugt (mittlere Orientierung $\left.=184^{\circ}\right)(A b b 5)$.

\section{Apis mellifera / wildlebende Bienen- völker / Nidifikation / Nistplatz}

\section{REFERENCES}

Anonymous (1986) User's Guide SPSS ${ }^{X}$. 2nd ed. McGraw-Hill, NY

Avitabile A, Stafstrom DP, Donovan KJ (1978) Natural nest sites of honey bee colonies in trees in Connecticut, USA. J Apic Res 17, 222-226

Bailey LH, Bailey EZ (1976) Hortus Third. Macmillan Publishing Co NY

Batschelet E (1981) Circular Statistics in Biology. Academic Press, NY

Collins AM, Rinderer TE, Harbo JR, Bolten B (1982) Colony defense by Africanized and European honey bees. Science 218, 72-74

De Jong $D$ (1982) Orientation of comb building by honeybees. J Comp Physiol A 147, 495501

Griffin JR, Critchfield WB (1976) The distribution of forest trees in California. USDA For Serv Res Paper PSW-82

Ifantidis MD (1978) Wabenorientierung im Nest der Honigbiene (Apis mellifica L.).. Apidologie 9, 57-73

Pillsbury NH, Kirkley ML (1984) Equations for total, wood, and saw-log volume for thirteen California hardwoods. USDA For Serv Res Note PNW-414

Rinderer TE, Collins AM, Bolten AB, Harbo $R$ (1981) Size of nest cavities selected by swarms of Africanized honeybees in Venezuela. J Apic Res 20, 160-164

Seeley T (1977) Measurement of nest cavity volume by the honey bee (Apis mellifera). Behav Ecol Sociobiol 2, 201-227 
Seeley TD, Morse RA (1976) The nest of the honey bee (Apis mellifera L.). Insectes soc 23, 495-512

Seeley TD, Morse RA (1978) Nest site selection by the honey bee, Apis mellifera. Insectes $\operatorname{soc} 25,323-337$
Taber S (1979) A population of feral honey bee colonies. Am Bee J119, 842-847

Taylor OR, Otis GW (1978) Swarm boxes and Africanized honeybees: some preliminary observations. J Kansas Entomol Soc 51(4), 807-817 